\title{
Prosody and Information Structure in Chichewa*
}

\author{
Laura J. Downing \\ ZAS Berlin
}

Al Mtenje

University of Malawi

Bernd Pompino-Marschall

Humboldt-Universität Berlin

This paper presents preliminary results of a phonetic and phonological study of the Ntcheu dialect of Chichewa spoken by Al Mtenje (one of the co-authors). This study confirms Kanerva's (1990) work on Nkhotakota Chichewa showing that phonological re-phrasing is the primary cue to information structure in this language. It expands on Kanerva's work in several ways. First, we show that focus phrasing has intonational correlates, namely, the manipulation of downdrift and pause. Further, we show that there is a correlation between pitch prominence and discourse prominence at the left and right periphery which conditions dislocation to these positions. Finally, we show that focus and syntax are not the only factors which condition phonological phrasing in Chichewa.

\section{Introduction}

Kanerva's (1990) pioneering study of focus in Chichewa concentrates on the prosodic expression of in situ focus. The effect of in situ focus is illustrated in (1). Under neutral phrasing the entire VP is a single phonological phrase, as shown in (1b)). Narrowing the scope of focus within the Verb Phrase, as in (1c) - (1e), results in an increase in the number of phonological phrases. (The phonological phrases are indicated with parentheses; the phonological motivation for the phrasing is presented in the next section). No prosodic

\footnotetext{
* We would like to thank the audiences of the Bantu Grammar: Description and Theory IV workshop at the University of Leiden for useful feedback on this paper. Al Mtenje and Laura Downing would also like to thank the British Academy for funding this workshop and their participation in it through an International Network Grant.
} 
(intonational) correlates for these phrase boundaries are reported in previous work.

(1) Focus and phrasing in Nkhotakota Chichewa (Kanerva, 1990: 98, fig. (101))

(a) anaménya nyumbá ndí mwáála he hit house with rock 'He hit the house with a rock.'

(b) What did he do? (VP focus) (anaményá nyumbá ndí mwáála)

(c) What did he hit the house with? (Oblique PP focus) (anaményá nyumbá ndí mwáála)

(d) What did he hit with the rock? (Object NP focus) (anaményá nyuúmba) (ndí mwála)

(e) What did he do to the house with the (V focus) rock?

(anaméenya) (nyuúmba) (ndí mwáála)

Ex situ focus is not discussed in Kanerva (1990). This is surprising, as work like Bresnan \& Mchombo (1987) shows that word order is rather free in Chichewa. In other Southern Bantu languages, like Makua (Stucky 1985), word order variation correlates with distinct information structures. However, the influence of word order variation on information structure or prosody has not received detailed attention in previous work on Chichewa.

In this paper, we present preliminary results of a study of the interaction of both in situ and ex situ focus (or discourse prominence) with prosody in Al Mtenje's dialect of Chichewa (Ntcheu Chichewa). The paper is organized as follows. First, we give a background sketch, from previous studies, on phonological and syntactic phrasing in Chichewa. Then we present our findings, which expand on earlier work in the following ways. First, we show that the phonological phrasing induced by focus does, in fact, have intonational correlates. We then show that word order is not as free as reported in earlier work, as there are information structure asymmetries at the left vs. right periphery. Finally, we show that focus and syntax are not the only factors which condition phonological phrasing in Chichewa. The final section presents conclusions and issues for further research.

\section{Background on syntactic and phonological phrasing in Chichewa}

Kanerva (1990) argues that two main factors condition phonological phrasing in Chichewa: syntax and focus. Sentences in Chichewa have three main subconstituents - an optional Subject NP, an obligatory VP and an optional Topic NP - which Bresnan \& Mchombo (1987), Kanerva (1990) and Mchombo 
(2004) suggest can all be freely ordered. Each of these three constituents, when they co-occur, is parsed into its own phonological phrase (Bresnan \& Kanerva 1989; Kanerva 1990). Important cues to phonological phrase boundaries are that there are no High tones on phrase-final vowels in the Nkhotakota dialect of Chichewa analyzed in Kanerva (1990), and phrase penult vowels are lengthened. ${ }^{1}$ The data in (2) illustrates syntactically-motivated phonological phrasing. As shown in (2b) and (2c), dislocated (object) NPs - Topics - are in a distinct syntactic and phonological phrase, and can occur in either order with respect to the VP:

(2) (a) (Subj) (VP) - Kanerva (1990: 103, fig (114b))

$\begin{array}{llll}\text { (mwaána) } & \text { (anapézá } & \text { galú } & \text { kúdáambo) } \\ \text { 1.child } & 1 \text {-found } & \text { dog } & \text { at swamp }\end{array}$

The child found the dog at the swamp.

(b) (Subj) (VP) (Top) - (Kanerva 1990: 107, fig (123b))

$\begin{array}{llll}\text { (mwaána) } & \text { (a-na-'m - pézá } & \text { kúdáambo) } & \text { (gaálu) } \\ \text { 1.child } & \text { 1. found it } & \text { at swamp } & \text { dog }\end{array}$

The child found it at the swamp, the dog.

(c) (Top) (VP) (Subj) - (Kanerva 1990: 102, fig (110c))

(a-leenje) (zi-ná-wá-luuma) ( njúuchi)

2.hunter 10-TA-2-bite 10.bees

The hunters, they bit them, the bees [did].

Focus also plays a role in conditioning phonological phrasing in Chichewa. In situ focus on an element of the VP is possible in Chichewa, and is realized, according to Kanerva (1990), only by a change in the phonological phrasing of the VP. The effect of focus on phonological phrasing is what Hyman (1999) and Truckenbrodt (1995) call 'boundary narrowing'. A phonological phrase boundary must follow the focused element, and each remaining constituent of the VP is parsed into a separate phonological phrase. As we saw in (1), this results in more, smaller phonological phrases under narrow focus. Another example of focus-induced boundary narrowing is provided in (3):

See Kanerva (1990) for detailed discussion of the range of phonological processes motivating phonological phrases in this dialect of Chichewa. 
(3) Nkhotakota Chichewa (Kanerva 1990: 98, fig (102))
(a) a-na-góná m-nyumbá yá Mávúuto. They slept in-house of Mavuto.
'They slept in Mavuto's house.'
(b) Where did they sleep?
(Object NP focus)
(a-na-góná m-nyumbá yá Mávúuto)
(c) What did they do in Mavuto's house?
( $\mathrm{V}$ focus) (a-na-góona) (m-nyumbá yá Mávúuto)

Kanerva (1990: chapter 5) shows that these phonological phrases are grouped into Intonational Phrases (IPs): the next highest constituent in the Prosodic Hierarchy (Nespor \& Vogel 1986; Selkirk 1986). IPs in Chichewa have the following prosodic correlates: intonational boundary tones, IP-final lengthening, and tonal catathesis (downdrift). These properties are illustrated in (4) and discussed in the lengthy descriptive quote which follows:

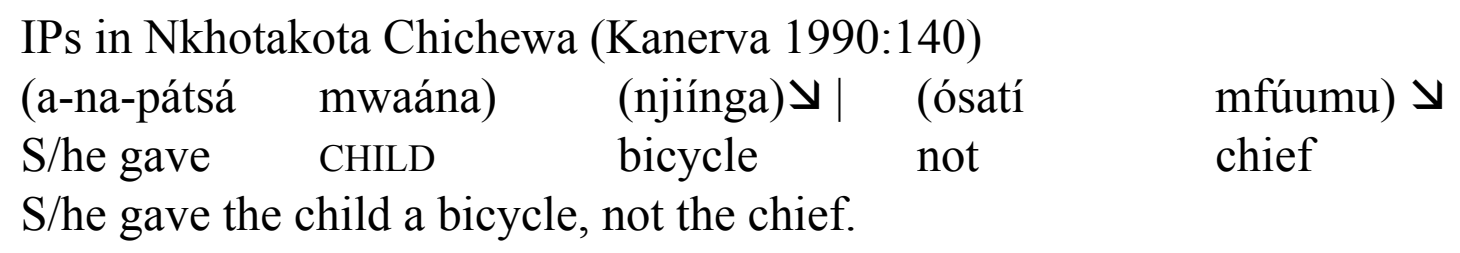

\begin{abstract}
"Both IPs in (4) end in low falling contours and show IP-final lengthening; in particular, the IP-penultimate syllable in njiinga is noticeably longer than the penultimate syllable in mwaána, which is lengthened only at the FP [phonological phrase] level [...]. Tonal catathesis occurs twice in the first IP, not only within the first [phonological phrase], but also between it and the second [phonological phrase]. No catathesis, however, occurs between the IPs; in fact, the High tones of the second IP are all higher pitched than those in njiínga and even mwaána."
\end{abstract}

Notice that there is no discussion here of boundary tones or register adjustments at phonological phrase boundaries, only at IP boundaries.

Like all good pioneering studies, Kanerva (1990) and the other work cited above both establish the groundwork for future research on phonological phrasing in Chichewa and raise new questions. Is there really no intonational correlate of phonological phrasing, especially phrasing conditioned by focus? Work like Selkirk (2004) proposes focus always has a culminative prosodic correlate, and Yip's (2002) tone survey shows focus has prosodic correlates in other tone languages. These studies motivate taking a second look at Chichewa focus phrase intonation. Is the order of Subject, VP and Topic really 'free'? That is, is there no difference in context of use or prosody associated with the 
different orders? Work like Stucky (1985) and Morimoto (2000) suggests word order variation is strongly influenced by discourse factors in Bantu languages, making it important to take a second look at Chichewa. The remainder of the paper addresses these questions, reporting new research on Ntcheu Chichewa, Al Mtenje's dialect. ${ }^{2}$

\section{Manipulation of downdrift/downstep and information structure}

\subsection{Downdrift, the suspension of downdrift and focus}

One of our most striking findings is that downdrift (catathesis) is manipulated at phonological phrase boundaries, providing an additional salient prosodic cue to focus. To return to the oft-cited examples in (1), we find differences both in phrasing and in pitch register in expressing in situ focus in Ntcheu Chichewa, as shown in (5). The context for each pronunciation is given in square brackets:

(5) Focus and phrasing in Ntcheu Chichewa
(a) anáménya nyumbá ndí mwáálá s/he hit house with rock
'S/he hit the house with a rock.'
(b) (A-ná-ménya nyumbá ndí mwáálá). [neutral declarative]
(c) (A-ná-ménya NYUÚMBÁ)! (ndí mwáálá). [Answers the question: A-ná-méenya chiyáani ndi mwáálá? 'What did he hit with the stone?']
(d) (A-ná-ménya nyuúmbá) (NDÍ MWÁÁLÁ). [no downstep] [Without downstep, emphasizes 'stone', but 'house' - as it is postverbal and not coreferenced by an $\mathrm{OM}$ - is also new information]
(e) (A-NÁ-MÉENYA)! (nyuúmbá)! (ndí mwáálá). [focus on hitting]

We find a number of differences in (5) compared to the description summarized in (1). First, there are dialectal tone differences. For example, as can be seen by

2 Other recent analyses of focus and phrasing in Chichewa - eg., Truckenbrodt (1995, 1999), Seidl (2001), Gussenhoven (2004), Samek-Lodovici (in press) - are reanalyses of the data presented in Kanerva (1990). As far as we know, this is the first new study of Chichewa focus prosody.

In the data in the remainder of the paper, ' $\|$ ' indicates pause; '!' indicates downstep. Parentheses continue to set off phonological phrases. 
comparing (1c) with (5c), retraction of a High tone from a phrase-final vowel onto the lengthened penult leaves a High tone on the phrase-final syllable in this dialect (see Mtenje (1987), Hyman \& Mtenje (1999) for more discussion). We also find a phrasing difference: there is an obligatory phrase break before a VPfinal focused element, as can be seen by comparing (5d) with (1c).

The most striking differences, though, lie in the realization of downdrift in (5b) vs. (5c) vs. (5d). Kanerva's (1990) discussion, quoted in (4), above, gives the impression that all of these phrases should have similar downdrift patterns in Nkhotakota Chichewa. Our phonetic study shows that focus interferes with the realization of downdrift, noticeably raising the expected pitch of a High tone in the focused phrase. As shown by the figures in (6) and the pitch tracks in Figure 1 , we still find downdrift across the phrase, no matter where focus is found. However, the pattern of downdrift is disrupted by focus:

(6) Pitch of High tones in $(5 b, c, d):^{3}$

$\begin{array}{lllll}\text { (5b) } & \frac{\mathrm{H} 1}{140} & \frac{\mathrm{H} 2}{115} & \frac{\mathrm{H} 3}{102} & \text { [downdrift in neutral phrasing] } \\ \text { (5c) } & 155 & 134 & 101 & \text { [H3 is relatively much lower than H2] } \\ \text { (5d) } & 134 & 113 & 112 & \text { [no downdrift if H3 is in focus] }\end{array}$

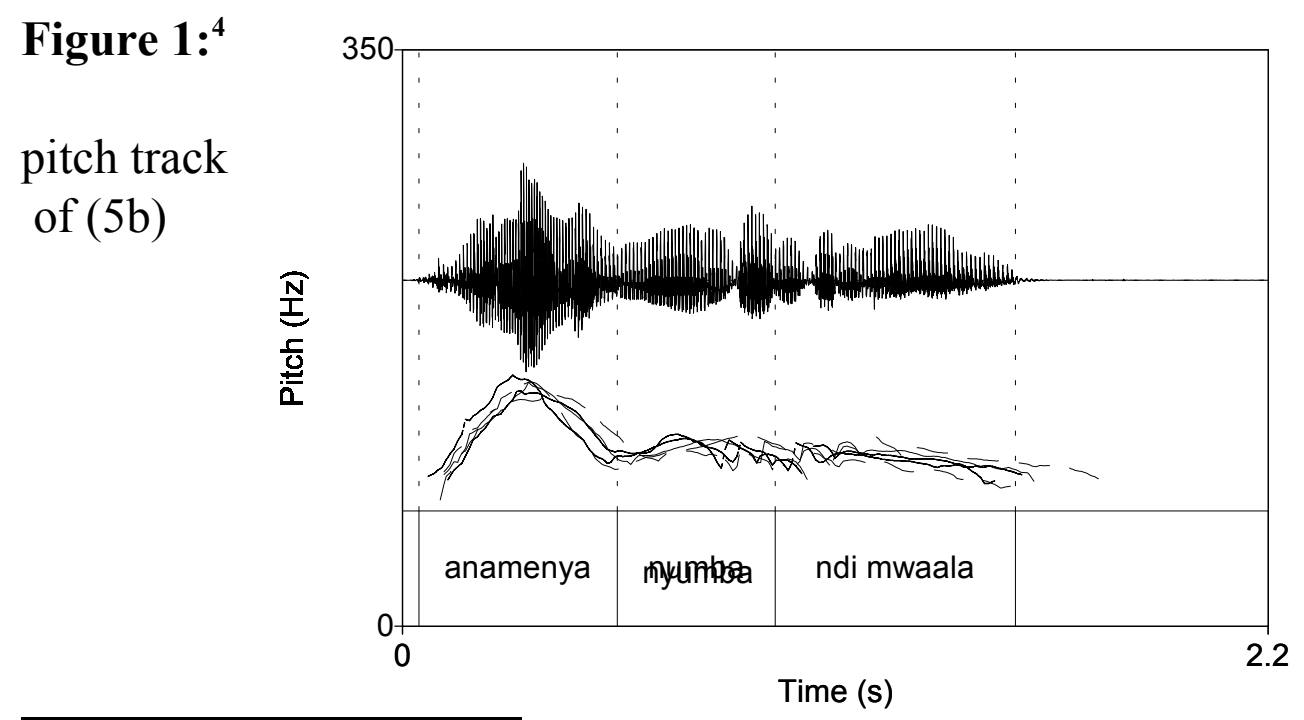

3 Representative $\mathrm{f}_{0}$ values [inHz] in one repetition out of five.

4 The figures - for purpose of demonstration only - always display the audiosignal of one repetition with its segmentation and labelling together with the overlaid pitch tracks of all five repetitions aligned at a constant time point before acoustical signal onset. N.B.: since no time warping was applied there are discrepancies with respect to $f_{0}$ peak locations and duration due to differences in speech rate and pausing between the repetitions of the same phrase. 
Prosody and Information Structure in Chichewa

pitch track of $(5 c)$

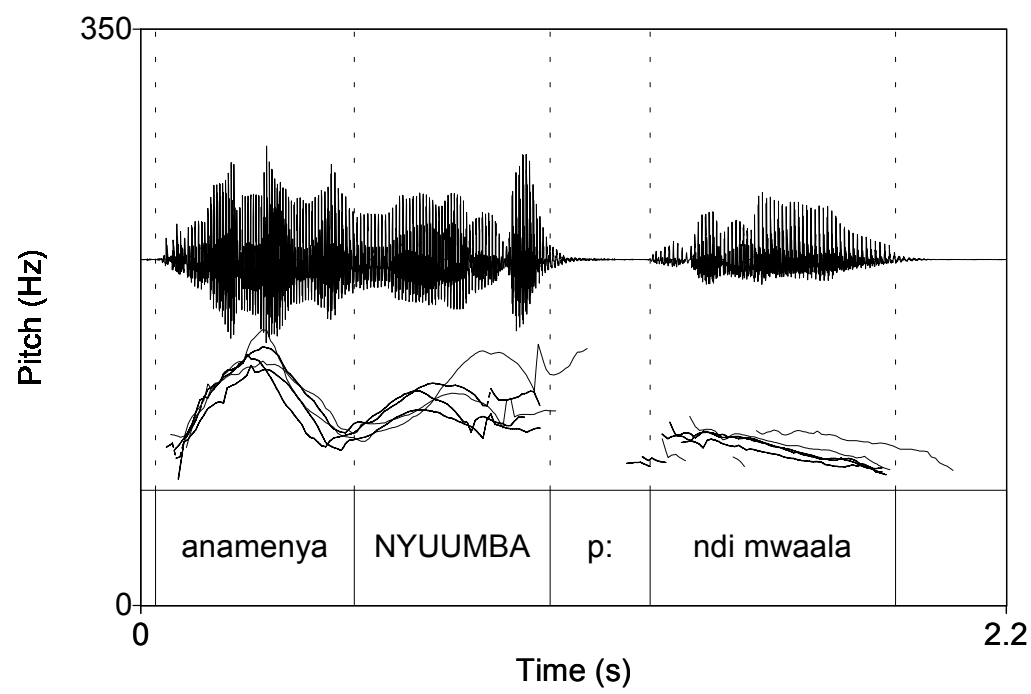

pitch track of $(5 \mathrm{~d})$

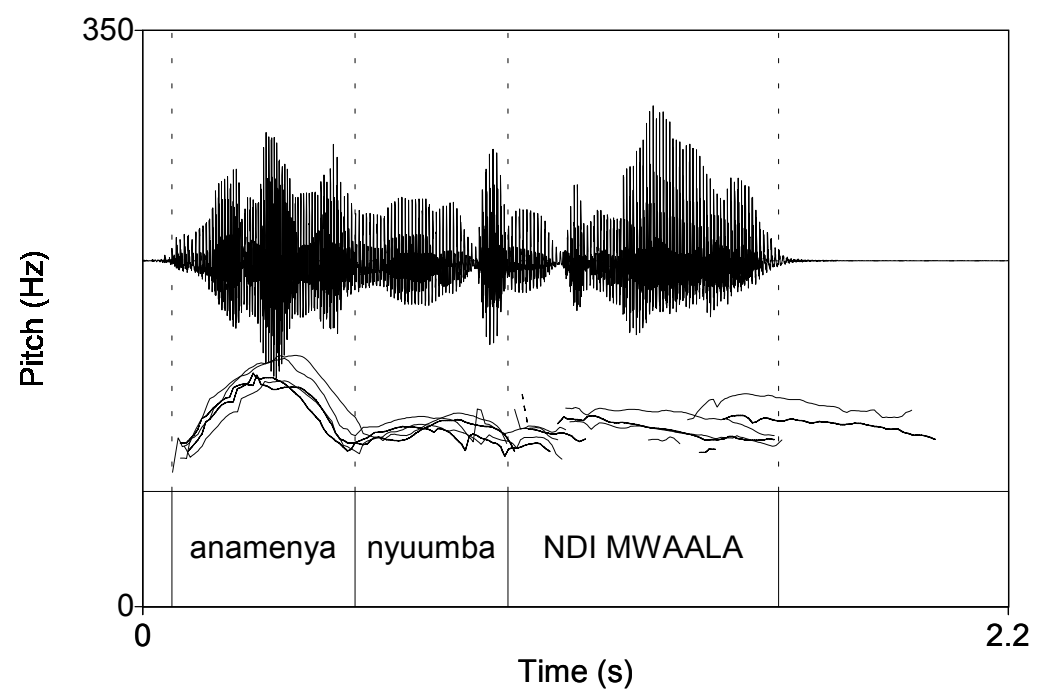

pitch track of $(5 e)$

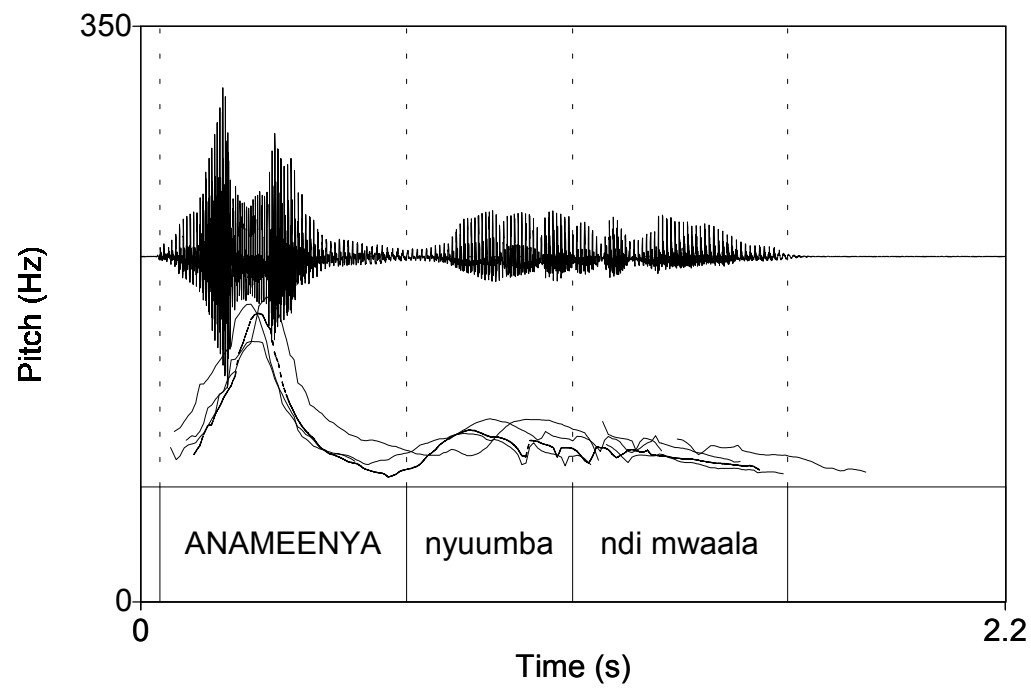


The same patterns of manipulation of downdrift triggered by focus are found consistently, as shown by the pitch tracks in Figures 2 and 3 for the data sets in (7) and (8), respectively:

(7)
(a) (A-ná-dyétsa
nyaní
nsóomba).
they fed
baboon
fish
[neutral declarative]

(b) (A-ná-dyétsa nyaání) (NSÓOMBA). [no downstep]

[Focus on 'fish']

(c) (A-ná-dyétsa NYAÁNí)! (nsóomba).

[With downstep, focus on 'baboon'. Answers question: A-ná-dyétsa ndaání nsóomba? 'Who did they feed fish to?']

Figure 2:

pitch track of (7a)
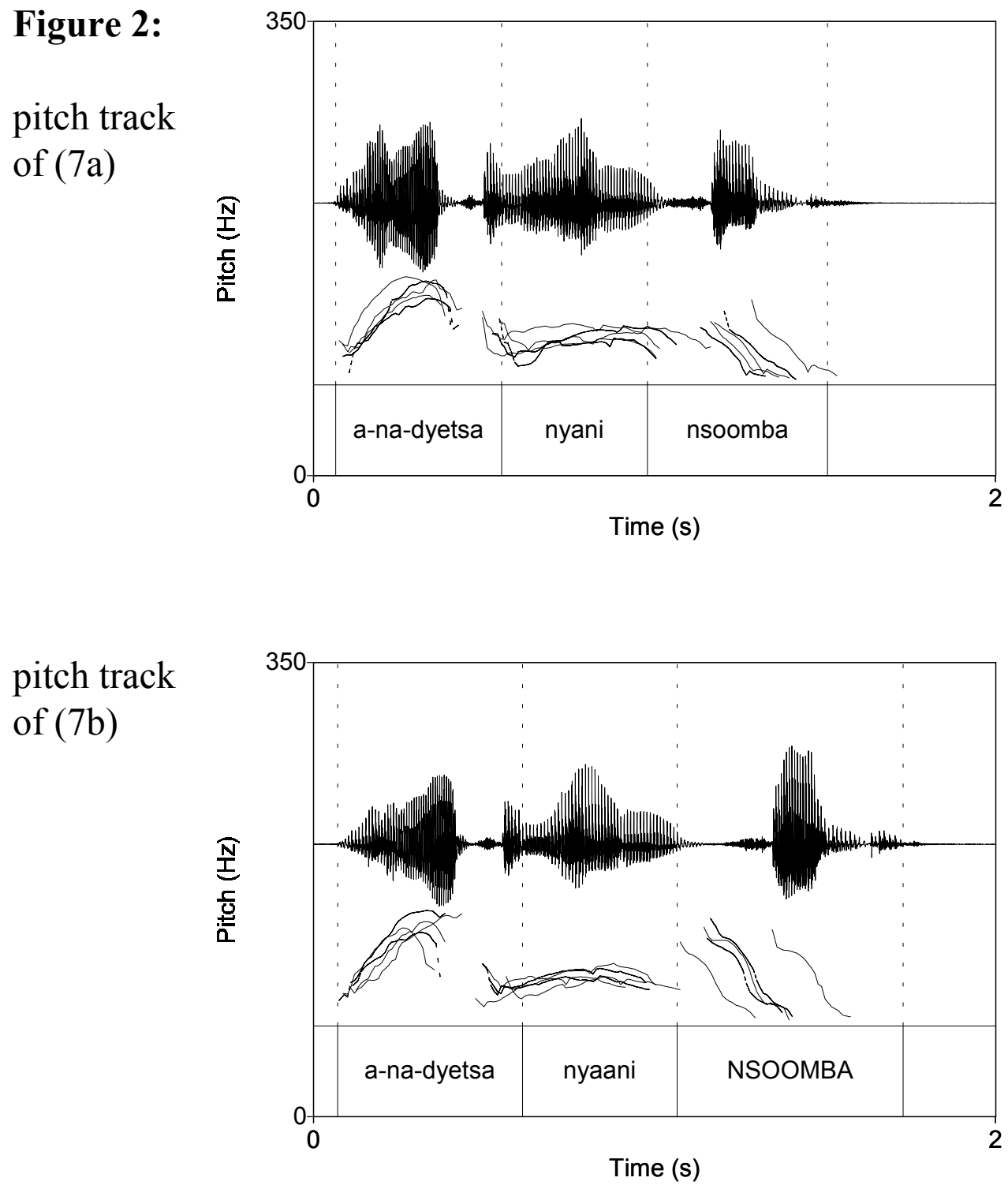
pitch track of $(7 \mathrm{c})$

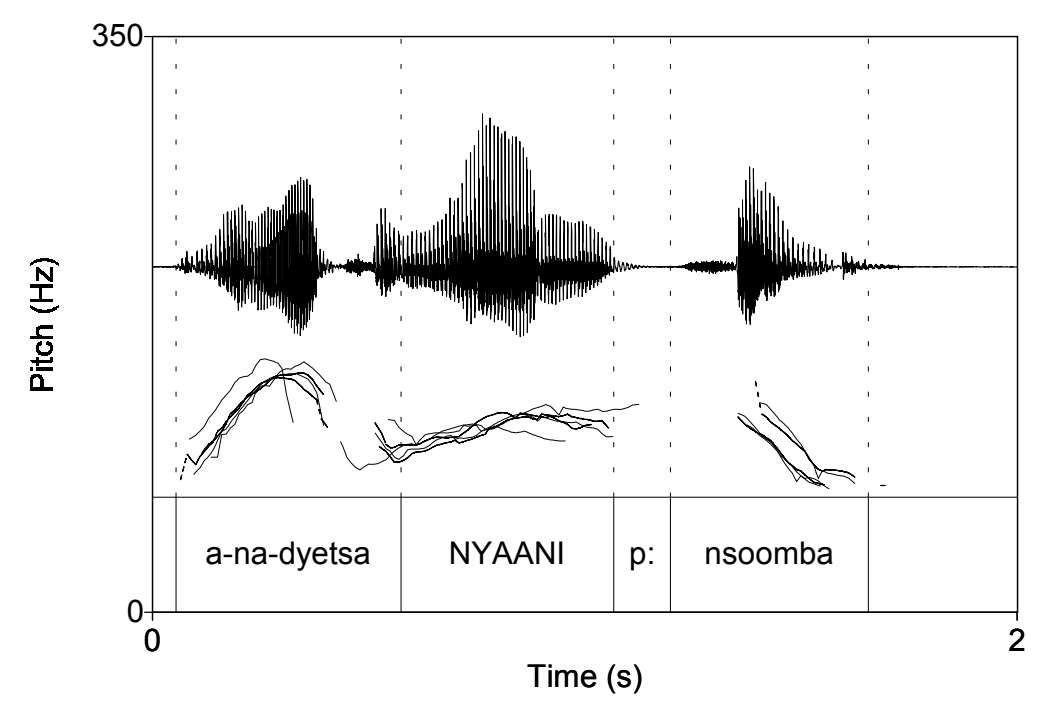

(8) (a) (Mfúumu) ! (i-ná-pátsa mwaná zóóváala). chief gave child clothes [neutral declarative]

(b) (A-ná-'m-patsa ZóóvÁALA)! (mwaáná). [Answers question: A-ná-'m-patsa chiyáani mwaáná?

'What did they give to the child?' 'Clothes, and not something else.']

(c) (A-ná-pátsa MWAÁNÁ) ! (zóóváala).

[Answers question: A-ná-pátsa ndááni zóóváala?

'Who did they give clothes to?']

(d) (A-ná-pátsa mwaáná) (ZÓóvÁALA). [no downstep]

[If no downstep, then focus on 'clothes'; 'child' is also new information as it is positioned right after the verb]

\section{Figure 3: ${ }^{5}$}

pitch track

of $(8 b)$

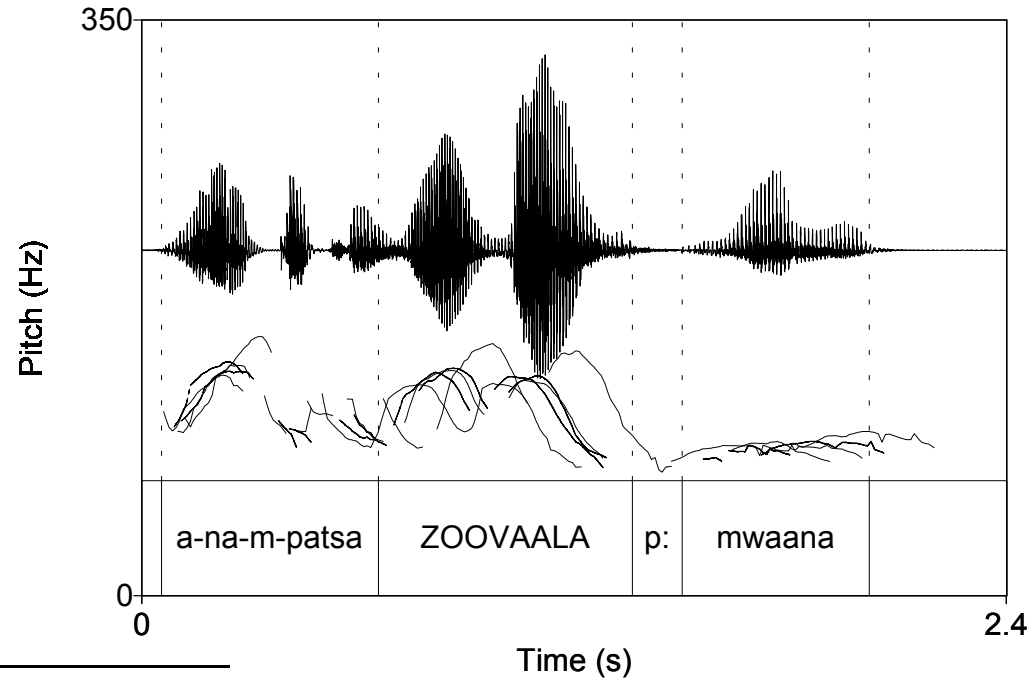

Time (s)

5 For discussion of the different timing of the pitch tracks cf. footnote 4 . 
pitch track of $(8 \mathrm{c})$

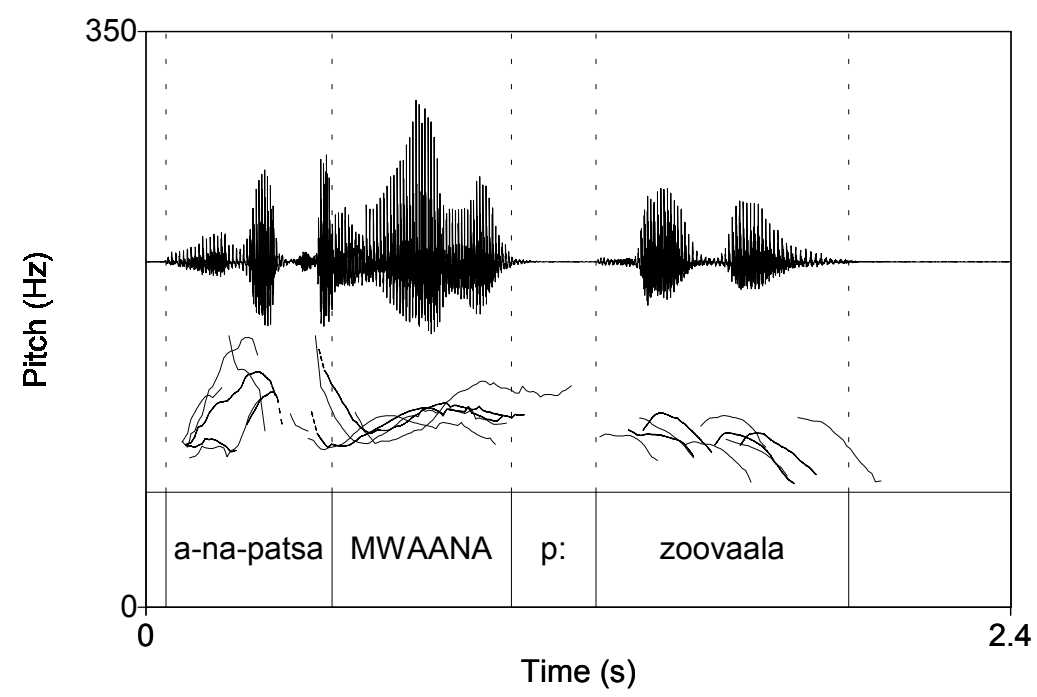

pitch track of $(8 d)$

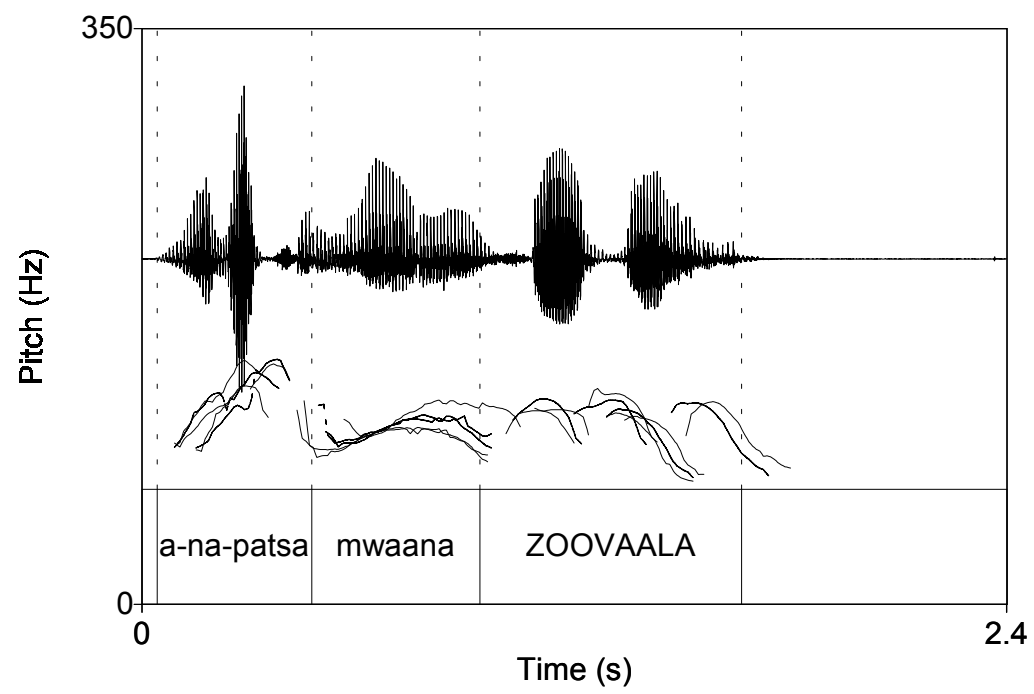

The data in (9) present a further set of examples which illustrate the same downdrift patterns. (To save space, pitch tracks for this data set are not provided.)

(9) (a) (A-ná-pézá galú kudáambo). $\mathrm{s} /$ he found $\quad \operatorname{dog}$ in swamp) [neutral declarative]

(b) (A-ná-pézá GAÁLÚ) ! (kudáambo). [Answers question: A-ná-pézá chiyáani kudáambo?

'What did they find in the swamp?']

(c) (A-ná-pézá gaálú) (KUDÁAMBO). [no downstep]

[Focus on 'swamp' if no downstep; 'dog' is also new information] 
To sum up this section, focus does have an intonational correlate in Ntcheu Chichewa: the expected degree of downdrift is violated. If the focused element is not the last word of the phrase, its High tones are raised enough to create a steep fall to the next High tone, giving what Downing (2004a,b) calls an 'antiaccent' effect. That is, the focused element is not made prominent by giving it the culminative pitch height of the utterance - this is what is typically meant by 'accent'. Rather, it is made prominent by raising the pitch enough to make the following elements relatively much lower in pitch - this is what is meant by 'anti-accent'. If the focused word is final in the phrase, the expected lowering of its pitch due to downdrift is suspended. This violation of expected downdrift patterns in tonal sequences triggered by focus makes manipulation of pitch register at phonological phrase boundaries an additional prosodic cue to focus.

\subsection{Downdrift and positions of contrast}

A second striking finding is that pitch height asymmetries correlate with information structure asymmetries for dislocated (Topic) NPs at the left- vs. right periphery. As shown in (2), Subject and Topic NPs can occur either before or after the VP in Chichewa. The previous work on Nkhotakota Chichewa, cited above, suggests that this ordering is free. Our work shows that the relative order of sentential constituents has discourse consequences. Sentence-initial Topic/Subject is understood as contrastive and discourse prominent. Sentencefinal Topic/Subject cannot be contrastive; it is downplayed, discourse-old information. When two NPs precede (or follow) the VP, the order of discourse salience matches their 'left to right' order of occurrence. This is illustrated by the data sets in (10) and (11):

(10) (a) (Mikáango)

|l! (mbúzí iizi)! (i-ná-zí-saaka).

lions goats these they hunted them.

The lions hunted these goats.

[focus on 'lions' as topic; more prominence on 'these goats' than if it follows verb]

(b) (I-NÁ-ZÍ-SAAKA) $\|$ ! (mikáango) $\|$ ! (mbúzí iizi).

[Emphasizes the hunting]

(c) (Mbúzí iizi) || ! (mikáango) || ! (i-ná-zí-saaka).

[Emphasis on 'goats' as contrastive topic; 'lions' highlighted compared to 'hunting': each downstepped item less discourse prominent] 
(d) (Mbúzí iizi) || ! (i-ná-zí-saaka) || ! (mikáango).

[Emphasis on 'goats' as contrastive topic; 'hunting' highlighted compared to 'lions']
(a) (ALEÉNDÓ)
|| ! (a-ná-'m-dyetsa
nsóomba). visitors fed him fish

[Answers question: Ndaání á-ná-m-dyétsá nsóomba?

'Who fed him fish?']

(b) (A-ná-'m-dyetsa nsóomba)! (aleéndó).

[Answers question: A-ná-'m-taání nyaání alééndó?

'What did the visitors do to the baboon?']

(c) (A-ná-'m-dyetsa nsóomba) (aleéndó). [no downstep]

[Emphasis is on 'visitors' as choice in a known list of possibilities: A-ná-m-dyétsá nsóomba ndaání? ‘WHO fed him fish?’]

The contrast in the discourse function and pitch for the word for 'visitors' in (11b) and (11c) is especially striking. In (11b), when the word is right-dislocated and downstepped, it is clearly old information, an afterthought. When downdrift is suspended for this word, as in (11c), then it can be a contrastive reiteration of old information.

To sum up this section, word order variation is not free in Ntcheu Chichewa but rather reflects discourse salience and contrast. It is not an accident that positions of relative discourse salience are realized sentence-initially. Prosodically, recall that downdrift across an utterance has as a result that sentence-initial elements are pronounced with the highest pitch and sentencefinal with the lowest pitch. What we find, then, is that relative pitch prominence correlates with relative discourse prominence. Due to downdrift, sentence-initial elements are prosodically more salient, realized at a relatively higher pitch.

\section{$4 \quad$ The role of pause as a cue to structure}

Another common cue to phonological phrase boundaries, in our study, is pause. As we show in this section, the placement of pauses is, in fact, often an important cue to the information structure or grammatical structure of the sentence. 


\subsection{Information structure and pause}

Often pauses occur in positions one might expect, for example, to set off dislocated Topic NPs. The data in (12) - (14) illustrates the correlation between pause and left-dislocation of NPs:

(12) (a) (A-ná-pézá galú kudáambo).

$\mathrm{s} /$ he found $\operatorname{dog}$ at swamp)

[neutral declarative]

(b) (Kudáambo) $\|$ ! (a-ná-pézá gaálú).

[Answers question: Ndí kúuti á-ná-pezá gáálú?

It is where that $\mathrm{s} / \mathrm{he}$ found the dog?]

(13) (a) (A-ná-dyétsedwa nsómbá ndí mávúuto).

They were fed fish by Mavuto

[Answers question: A-ná-táání anthu awa?

'What happened to these people?']

(b) (Nsóomba) || ! (a-ná-dyétsedwa ndí mávúuto).

[Big pause required, plus right context: Two things were given as food, meat and fish. As for the fish, it was given by Mavuto. Meat given by someone else.]

(14) (a) (Mikáango) ! (i-ná-sáka mbúzí iizi). lions hunted goats these [neutral phrasing]

(b) (I-NÁ-Zí-SAAKA) $\|$ ! (mikáango) $\|$ ! (mbúzí iizi).

[Emphasizes the hunting]

Focus can also be accompanied by pause. As we saw in the previous section, when a phonological phrase boundary follows a focused NP, a pause (as well as a downstep) generally marks the phrase boundary. This is clearly shown in the pitch tracks for (5c) and also (7c) and (8c). In those examples, pause is a secondary cue to focus.

Pause is sometimes the primary cue to focus. For example, the important difference between an in situ focused subject and in situ topic subject is the greater degree of pause following a focused subject. ${ }^{6}$

6 Kanerva's (1990: 103) study of Nkhotakota Chichewa shows no difference in pronunciation or phrasing when the subject is a topic vs. focused. Perhaps this is a dialect difference. 
(15) (a) (Mikáango) ! (i-ná-sáka mbúzí iizi). lions hunted goats these

Lions hunted these goats. [neutral phrasing]

(b) (MiKÁANGO)! ! (i-ná-sáka mbúzí iizi).

[focus on 'lions': contrasts them with other possible agent and answers the question: Ndaání á-ná-saká mbúzí iizi?

'Who hunted these goats?']

(16) (a) (Malúume) ! (a-ná-lémbera mkází kálaata). uncle s/he wrote woman letter [simple declarative]

(b) (MALÚUME) $\|$ ! (a-ná-lémbera mkází kálaata).

[Focus on 'uncle': Ndaání á-ná-lembélá mkází kálaata?

'Who wrote the letter to the woman?']

The pitch tracks in Figure 4 clearly show how pause correlates with a focused, new information subject (16b), ${ }^{7}$ while lack of pause correlates with the neutral, topic role of subject (16a).

\section{Figure 4:}

pitch track of (16a)

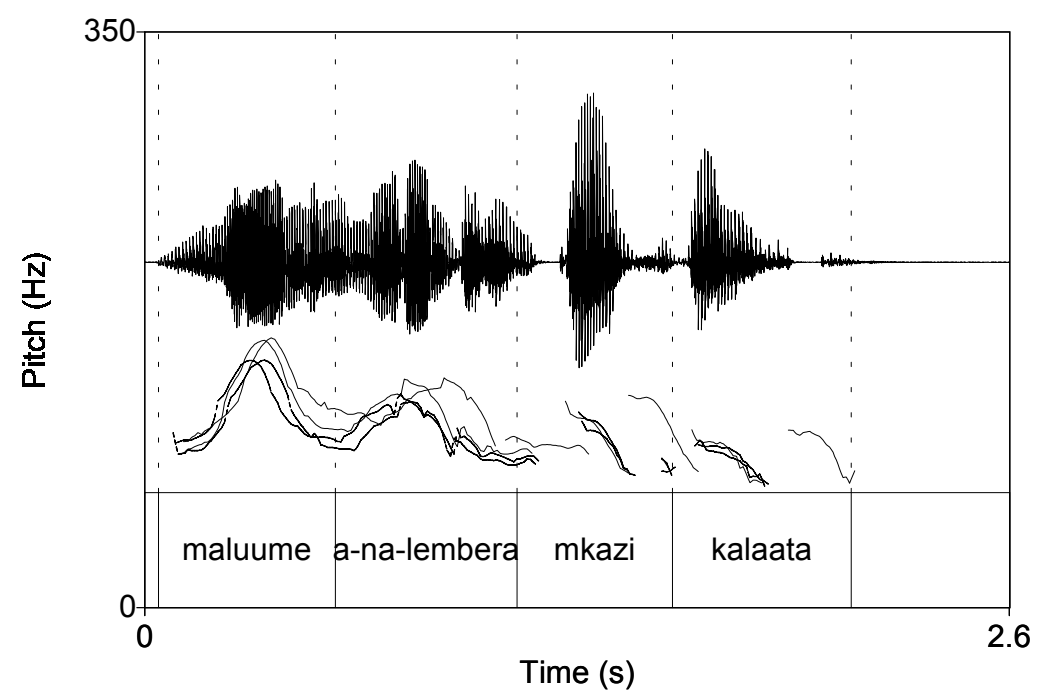

7 For discussion of the different timing of the pitch tracks cf. footnote 4 . 
pitch track of (16b)

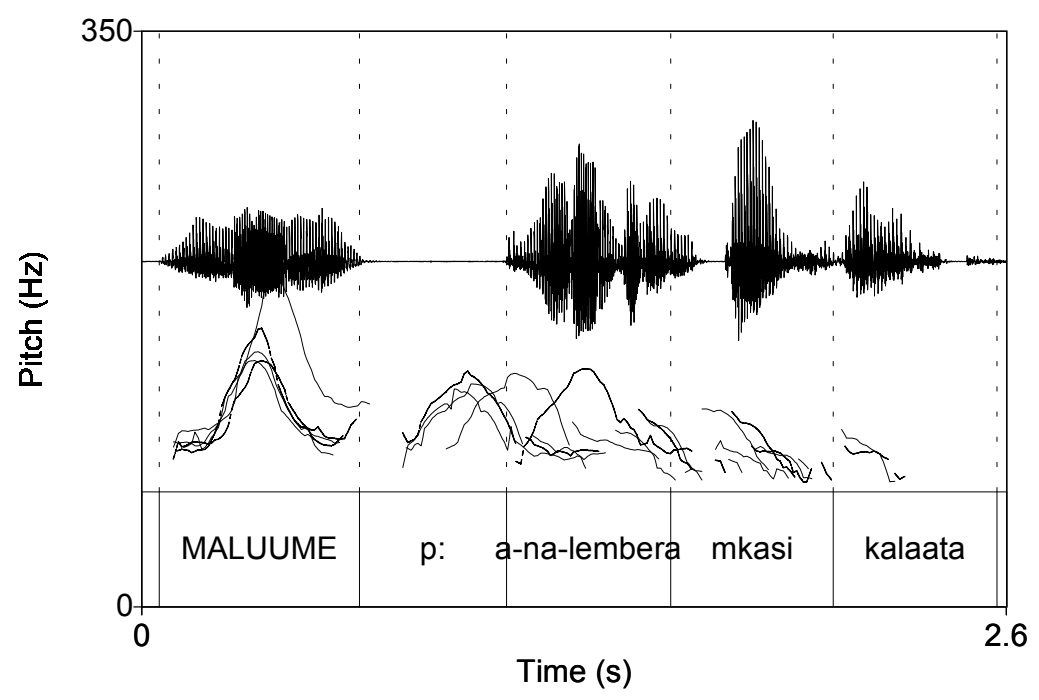

\subsection{Grammatical role and pause}

In some cases, differences in phonological phrasing and pause placement can change the grammatical role attributed to NPs. In the few examples we have, this use of pause seems to be most likely when the verbal morphology does not disambiguate the grammatical role. For example, in (17), 'woman' and 'uncle' belong to the same noun class. As a result, it is ambiguous from the verb agreement morphology which NP is the subject and which is the object. The contrastive placement of pauses in (17a) compared to (17b) disambiguates the grammatical role of these two NPs:

(17) (a) (mkáazi) \| (a-ná-mú-lembera malúume) ! (kálaata).
woman s/he wrote him uncle letter
['woman' is understood as the agent and 'uncle as the recipient]
(b) (mkáazi) $\|$ ! (a-ná-mú-lembeera) $\|$ ! (malúume)! (kálaata).
['woman' is understood as the patient and 'uncle' is the agent]

The pitch tracks in Figure 5 show the contrastive pause placements in (17a) vs. (17b) clearly. 


\section{Figure 5:}

pitch track of (17a)

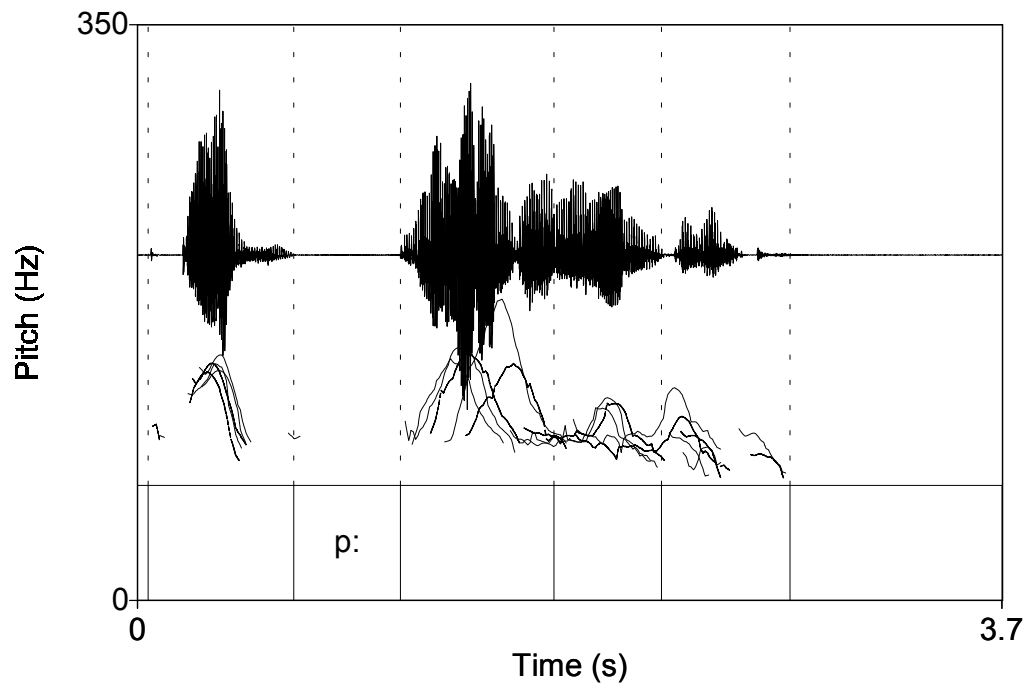

pitch track of (17b)

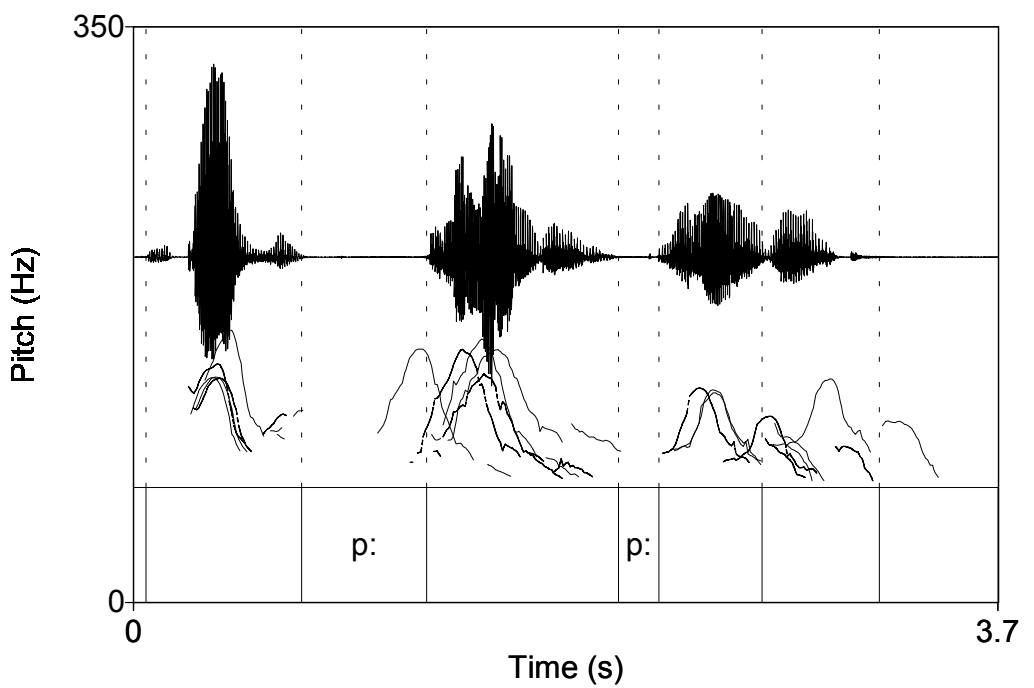

Phonological phrasing can play a similar role in disambiguating the grammatical role of NPs. The sentence in (18), like the one in (17), contains ambiguous verb agreement morphology. In this case, the object prefix (-m-) could refer either to 'child' or to a third human NP not mentioned in the sentence. If 'child' is phrased with verb, as in (18a), it is unambiguously understood as the recipient. If it is phrased separately, as in (18b), it is ambiguously either agent or recipient.

(18) (a) (mwaná ! a-ná-'m-patsa zóóváala) child $\quad \mathrm{s} / \mathrm{he}$-him-gave clothes

(b) (mwaáná)! (a-ná-'m-patsa zóóváala) 


\subsection{Mixed signals}

Surprisingly, in some 'neutral phrasings', no phonological phrase boundary or pause follows a sentence-initial NP, whether subject or object, but noticeable downstep still follows as if there were a phrase boundary. One example has already been seen in (18a), others are given below: ${ }^{8}$
(a) (Aleéndó)
! (a-ná-'m-dyetsa
Visitors fed him
nsóomba).
[neutral declarative]

(b) (Alendó ! a-ná-'m-dyetsa nsóomba). [neutral declarative]

(a) (Mpháatso) $\|$ ! (a-ná-péreka kwá mfúumu). gifts they gave to chief [As for gifts, they were given to the chief, and other items had something else happen; must pause to make it clear that 'gift' is the object if no OM is used.]

(b) (Mpháatso)! (a-ná-yí-pereka kwá mfúumu). ['gift' is simple topic, as if subject of a passive sentence]

(c) (Mphátsó ! a-ná-yí-pereka kwá mfúumu). [neutral declarative as in (20b)]

What is interesting in this data is that larger phonological phrasings continue to correlate with neutral information structure, while boundary narrowing adds some discourse prominence to the word set off by phrasing. It is also interesting to note that the phonological phrasings in (18a), (19b) and (20c) are not predicted by previous work on Chichewa, as the pre-verbal NPs should, in all these cases, be in separate phonological phrases to match the syntactic phrasing. This data emphasizes that focus and syntax are not the only factors conditioning phonological phrasing in Ntcheu Chichewa.

\section{Conclusion and issues for further research}

To sum up, our preliminary phonetic study of Ntcheu Chichewa provides a new perspective on both the prosody of focus and the function of word order

8 Some participants in the Leiden Workshop were not sure the downstep is as noticeable in examples like (19b) as the authors perceived. A phonetic study of data sets like these is necessary to decide this question. 
variation. One of our most significant findings is that downdrift is manipulated at phonological phrase boundaries as an additional cue to focus. Most work on focus has investigated the role of sentence accent as the primary cue to focus (Gussenhoven 1984，1996，1999，2004; Selkirk 1984，1995, 2004). Indeed, Truckenbrodt's (1995) reanalysis of Kanerva (1990) suggests that focused elements - as the heads of their utterances, by definition - must have sentential prominence. As Samek-Lodovici (in press) shows, theoretical problems are caused by Chichewa focus phrasing if focused elements do not, in fact, have sentential prominence. While the manipulations of downdrift resemble culminative focus accent in raising the pitch of focused constituents, we would argue that it is not equivalent to accent. No culminative prominence is given to the focused element, rather a relative prominence: the expected degree of downdrift is violated. This study, then, confirms work like Ladd (1996: 195196) which argues that accent is not a universal cue to focus. It also confirms work like Hayes \& Lahiri (1991), Ladd (1996: ch. 5) and Downing (2003) arguing that focus involves paradigmatic prominence, rather than culminative prominence. Words or phrases are recognized as being in narrow focus because they do not have the unmarked prosody that correlates with the 'neutral' pronunciation of the same phrase.

A further important role for downdrift is that it explains why word order is not actually free in Chichewa. We find an asymmetry in discourse prominence of sentence-initial topic - which is potentially contrastive - vs. downstepped sentence-final topic - which is in discourse 'oblivion.' There is a matching asymmetry in relative pitch height at the left vs. right periphery: sentence-initial high tones are highest in pitch. Due to downdrift, sentence-final high tones are lowest in pitch. What we find, then, is a correlation between pitch and discourse prominence asymmetries at the peripheries of the sentence. ${ }^{9}$

Our study also identifies additional roles for phonological phrasing and pause than those reported in Kanerva (1990). Syntactic structure and focus are not the only factors which condition phrasing. As shown in the preceding section, a sentence-initial NP is not always a separate phonological phrase, even though it is presumably always a separate syntactic constituent. Our study also shows that phrasing is a cue to grammatical role as well as focus and syntactic structure. Finally, we have shown that pause is a cue to subject focus, and that distinct pauses are required as a parsing aid with certain word orders when the verbal morphology does not unambiguously define the grammatical role. Pause

9 See Downing (2004a) for discussion of a similar correlation between pitch prominence and discourse prominence in Chitumbuka. See Hock (1998) for discussion of final reduction as a factor motivating pre-final focus position in non-Bantu languages. 
does not just occur at IP boundaries, as previous work on the distribution of pauses, like Nespor \& Vogel (1986) suggests.

We would like to close by identifying areas for future research. Further phonetic studies are clearly needed to test if similar prosody is found in other languages. For example, in Xhosa (Jokweni 1995) and Haya (Byarushengo et al. 1976) focus also conditions boundary narrowing. Do they also have similar manipulation of downdrift at these phonological phrase boundaries? Herero (Möhlig et al 2002) is reported to have register raising under focus. Is raising in Herero like Chichewa, where raising means suspension of downdrift? Or is it like stress-accent, where the focused element has the highest pitch of the utterance? We hope this study lays the foundation for pursuing these questions.

\section{References}

Bresnan, J. and S. Mchombo (1987) Topic, pronoun and agreement in Chichewa. Language 63: 741-782.

Bresnan, J. and J. Kanerva (1989) Locative inversion in Chichewa: a case study of factorization in grammar. Linguistic Inquiry 20: 1-50.

Byarushengo, E. R., L. M. Hyman and S. Tenenbaum (1976) Tone, accent, and assertion in Haya. In Larry M. Hyman, ed. Studies in Bantu Tonology (SCOPIL 3): 185-205.

Downing, L. J. (2003) Stress, tone and focus in Chichewa and Xhosa. In Rose-Juliet Anyanwu (ed.). Stress and Tone - the African Experience. Frankfurter Afrikanistische Blätter 15: 59-81.

Downing, L. J. (2004a) Focus and phrasing in Chitumbuka. Paper presented at CALL 34, University of Leiden, 23-25 August 2004.

Downing, L. J. (2004b) The prosody of focus in Bantu languages and the primacy of phrasing. Paper presented at the TIE Conference, Santorini (Greece), 9-11 September 2004.

Gussenhoven, C. (1984) On the Grammar and Semantics of Sentence Accents. Dordrecht: Foris.

Gussenhoven, C. (1996) Sentence accents and argument structure. In I.M. Roca, ed. Thematic Structure: Its Role in Grammar. Berlin: Foris, 79-106.

Gussenhoven, C. (1999) On the limits of Focus Projection in English. In Peter Bosch \& Rob van der Sandt, eds. Focus: Linguistic, Cognitive, and Computational Perspectives. Cambridge: Cambridge University Press, 43-55.

Gussenhoven, C. (2004) The Phonology of Tone and Intonation. Cambridge: Cambridge University Press.

Hayes, B. and A. Lahiri (1991) Bengali Intonational Phonology. NLLT 9, 47-96.

Hock, H. H. (1998) Finality, prosody and change. In Proceedings of LP'98, O. Fujimura, B.D. Joseph and B. Palek (eds.). Prague: The Karolinum Press: 15-30.

Hyman, L. M. (1999) The Interaction between Focus and Tone in Bantu. In: Georges Rebuschi and Laurie Tuller (eds.). The Grammar of Focus. Amsterdam: John Benjamins: 151-177. 
Hyman, L. M. and A. Mtenje (1999) Prosodic Morphology and tone: the case of Chichewa. In René Kager, Harry van der Hulst and Wim Zonneveld, (eds.). The ProsodyMorphology Interface. Cambridge: Cambridge University Press: 90-133.

Jokweni, M. W. (1995) Aspects of IsiXhosa Phrasal Phonology. Ph.D. dissertation, University of Illinois at Urbana-Champaign.

Kanerva, J. (1990) Focus and Phrasing in Chichewa Phonology. New York: Garland.

Ladd, D. R. (1996) Intonational Phonology. Cambridge: Cambridge University Press.

Mchombo, S. (2004) The Syntax of Chichewa. Cambridge: Cambridge University Press.

Möhlig, W. J.G., L. Marten and J. U. Kavari (2002) A Grammatical Sketch of Herero (Otjiherero). Köln: Rüdiger Köppe Verlag.

Morimoto, Y. (2000) Discourse Configurationality in Bantu Morphosyntax. Ph.D. dissertation, Stanford.

Mtenje, A. (1987) Tone shift principles in the Chichewa verb: a case for a tone lexicon. Lingua 72, 169-209.

Nespor, M. and I. Vogel (1986) Prosodic Phonology. Dordrecht: Foris Publications.

Samek-Lodovici, V. (in press) Prosody-syntax interaction in the expression of focus. NLLT 23.

Seidl, A. (2001) Minimal Indirect Reference: A Theory of the Syntax-Phonology Interface. London: Routledge.

Selkirk, E. O. (1984) Phonology and Syntax: The Relation between Sound and Structure. Cambridge, Mass.: MIT Press.

Selkirk, E. O. (1986) On derived domains in sentence phonology. Phonology Yearbook 3: 371-405.

Selkirk, E. O. (1995) Sentence prosody: intonation, stress and phrasing. In John A. Goldsmith, (ed.). The Handbook of Phonological Theory. Cambridge, Mass.: Blackwell, 550-569.

Selkirk, E. O. (2004) Bengali intonation revisited. In Chungmin Lee, Matthew Gordon \& Daniel Büring (eds.), Topic and Focus: A Cross-Linguistic Perspective. Dordrecht: Kluwer, 217-246.

Stucky, Susan U. 1985. Order in Makua Syntax. New York: Garland.

Truckenbrodt, H. (1995) Phonological Phrases: Their Relation to Syntax, Focus, and Prominence. Ph.D. dissertation, MIT.

Yip, M. (2002) Tone. Cambridge: Cambridge University Press. 